\title{
REALOKASI KARTU PRA KERJA DALAM MENDUKUNG INTENSIFIKASI SEKTOR PERTANIAN
}

\author{
Abi Pratiwa Siregar \& Nadia Octaviana \\ Fakultas Pertanian, Prodi Ekonomi Pertanian dan Agribisnis, Universitas Gadjah Mada \\ JI. Flora, Bulaksumur, Daerah Istimewa Yogyakarta, Telp (0274) 563062, email: \\ abipratiwasiregar@ugm.ac.id
}

\begin{abstract}
Abstrak
Seiring perkembangan pandemi COVID-19 di Indonesia, pemerintah mengeluarkan kebijakan Kartu Pra Kerja sebagai salah satu solusi dalam penanganan dampak COVID-19 dari aspek ketenagakerjaan. Anggaran senilai 20 triliun rupiah dinilai sangat besar dibandingkan dengan dampak yang akan dirasakan, khususnya pada saat seperti ini dimana para penyedia lapangan kerja cenderung membatasi rekrutmen pekerja baru atau bahkan merumahkan beberapa pekerjanya. Oleh karena itu, realokasi anggaran kartu pra kerja ke sektor pertanian dianggap alternatif yang tepat, mengingat sektor pertanian merupakan padat karya dan merupakan penyedia kebutuhan pokok masyarakat. Tujuan penelitian ini adalah: 1) melakukan kajian peran sektor pertanian terhadap pembangunan ekonomi di Indonesia, dan 2) melakukan simulasi terhadap realokasi anggaran kartu pra kerja untuk intensifikasi pertanian. Metode penelitian ini adalah deskriptif analitis menggunakan data sekunder yang berasal dari Badan Pusat Statistik dan Kementerian Pertanian. Hasil penelitian menunjukkan bahwa sektor pertanian memiliki kontribusi relatif besar terhadap pendapatan domestik bruto dan penyerapan tenaga kerja. Lebih lanjut, hasil simulasi realokasi anggaran menggambarkan bahwa kebijakan mengalihkan beberapa pos anggaran kartu pra kerja untuk intensifikasi pertanian merupakan hal tepat, terutama dalam kaitannya efektifitas penyerapan tenaga kerja dan penyaluran bantuan, serta untuk menjaga ketersediaan bahan pangan di masyarakat.
\end{abstract}

Kata kunci: COVID-19, intensifikasi pertanian, kartu pra kerja, pengangguran, realokasi anggaran

\begin{abstract}
As the development of the COVID-19 pandemic in Indonesia, the government issued a Pre-Work Card (Kartu Pra Kerja) policy as one of the solutions in handling the impact of COVID-19 from the labor aspect. A budget of 20 trillion rupiahs is considered very large compared to the impact that will be felt, especially at a time like this when employment providers tend to limit the recruitment of new workers or even lay off some workers. Therefore, the reallocation of the Pre-Work Card (Kartu Pra Kerja) budget to the agricultural sector is considered an appropriate alternative, given that the agricultural sector is labor-intensive and is a provider of people's basic needs. The objectives of this study are to study the role of the agricultural sector on economic development in Indonesia and to simulate the reallocation of pre-work card budgets for agricultural intensification. This research method is an analytical descriptive using secondary data from the Central Statistics Agency and the Ministry of Agriculture. The results showed that the agricultural sector had a relatively large contribution to gross domestic income and employment. Furthermore, the results of the budget reallocation simulation illustrate that the policy of diverting some pre-work card budget posts for agricultural intensification is appropriate, especially concerning the effectiveness of labor absorption and distribution of aid, and to maintain the availability of food in the community.
\end{abstract}

Keywords: agricultural intensification, budget reallocation, COVID-19, pre-work card, unemployment

\section{PENDAHULUAN}

Pembangungan ekonomi menghadapi berbagai tantangan dari waktu ke waktu,

salah satu di antaranya adalah bagaimana memperluas kesempatan kerja secara terus 
menerus, agar jumlah maupun persentase pengangguran dapat berkurang. $\mathrm{Di}$ Indonesia, terdapat 3 kategori pengangguran, yaitu: a) pengangguran terselubung, yaitu tenaga kerja yang tidak bekerja secara maksimal karena suatu alasan tertentu, b) setengah menganggur, tenaga kerja yang kurang dari 35 jam per minggu, dan c) pengangguran terbuka, yaitu individu yang tidak memiliki pekerjaan (Franita, 2016). Untuk kategori paling akhir, maka dampak yang dapat dirasakan adalah ketiadaan pendapatan, sedangkan seharihari harus mengeluarkan biaya untuk memenuhi kebutuhan pokok. Atas dasar hal tersebut, Prasetyoningrum \& Sukmawati (2018) menyimpulkan bahwa pengangguran memiliki pengaruh positif terhadap tingkat kemiskinan.

Perluasan kesempatan kerja bisa dilakukan salah satunya dengan meningkatkan pertumbuhan ekonomi. Apabila pertumbuhan ekonomi meningkat sebesar 1 persen, maka tingkat pengangguran diproyeksikan menurun sekitar 1,34\% (Qomariyah, 2013). Hal ini sejalan dengan Hukum Okun yang menyatakan bahwa adanya kenaikan dari PDB akan mendorong berkurangnya pengangguran (Astuti, 2016). Terjadinya pertumbuhan ekonomi menunjukkan bahwa jumlah produk baik barang maupun jasa yang diproduksi saat ini relatif lebih besar dibandingkan dengan periode sebelumnya. Kenaikan produksi tersebut direspon dengan meningkatnya permintaan terhadap faktor produksi, khususnya tenaga kerja.

Pada tahun 2020, dunia dilanda penyakit COVID-19 (coronavirus disease) yang disebabkan oleh SARS-CoV-2 Pada tanggal 2 Maret 2020, Indonesia telah melaporkan 2 kasus konfirmasi COVID-19 (Direktorat Jenderal Pencegahan dan Pengendalian Penyakit, 2020). Seiring berjalannya waktu, jumlah kasus terus bertambah dan per 30 April 2020, jumlah kasus positif mencapai
10.118 orang (Gugus Tugas Percepatan Penanganan COVID-19, 2020). Hal ini dikarenakan COVID-19 dapat mudah menyebar apabila individu yang telah terinfeksi berkumpul dan berinteraksi dengan orang lain. Untuk mengantisipasi penyebaran ini, kemudian pemerintah menyarankan untuk membatasi interaksi dan pada kasus paling buruk diterapkan pembatasan sosial berskala besar (PSBB). Hal ini berdampak pada dunia usaha, dimana omset menjadi menurun sehingga harus adalah mengurangi jumlah karyawan.

Kementerian Ketenagakerjaan dan BPJS memperkirakan pandemi COVID-19 berdampak pada kurang lebih 2,8 juta tenaga kerja dengan rincian, 1,7 juta pekerja formal dirumahkan, 794,4 ribu pekerja formal di PHK, 282 ribu pekerja informal yang usahanya terganggu dan 100 ribu pekerja migran dipulangkan (Jayani, 2020). Untuk mengatasi hal tersebut, pemerintah akhirnya memutuskan untuk mempercepat realisasi program Kartu Pra Kerja 2020 secara nasional. Pelaksanaan dan penyesuaian fokus dari Program Kartu Pra Kerja dipercepat sebagai salah satu langkah implementasi Instruksi Presiden (Inpres) Nomor 4 Tahun 2020 tentang Re-Focusing Kegiatan, Anggaran, serta Pengadaan Barang dan Jasa untuk Percepatan Penanganan Coronavirus Disease 2019 (Covid-19).

Pada akhir tahun 2019, pemerintah menetapkan target sasaran sebanyak 2 juta peserta dengan insentif Rp. 300.000 - Rp. 500.000 per peserta. Pelatihan dilaksanakan melalui platform digital atau lembaga pelatihan kerja pemerintah/swasta/industri. Total anggaran yang dibutuhkan mencapai Rp. 10 triliun (Lidwina, 2019). Akibat COVID19 , pemerintah menaikkan anggaran hingga Rp. 20 triliun untuk target sasaran sebanyak 5,6 juta peserta. Adapun rincian pengeluarannya adalah 1 juta rupiah per 
orang dibayarkan langsung kepada lembaga pelatihan, insentif pelatihan sebesar 2,4 juta rupiah per orang, dan isnetif survei keberkerjaan sebesar 150 ribu rupiah per orang.

Jika di awal rencana Kartu Pra Kerja terbuka untuk umum, termasuk yang sudah bekerja, saat ini diprioritaskan untuk pekerja maupun pelaku usaha mikro/kecil yang terdampak pandemi COVID-19. Apabila dilihat dari dampak sektoral, sektor industri yang terpengaruh COVID-19 antara lain pariwisata, keuangan, transportasi, pertambangan, konstruksi, otomotif, dan UMKM (Jayani, 2020). Di sisi lain, sektor pertanian diproyeksikan akan bertahan, bahkan tumbuh seperti halnya ketika terjadi krisis pada tahun 1998. Yudanto \& Santoso (1998) mengungkapkan bahwa indeks harga saham sektor pertanian selalu lebih besar dari sektor lainnya. Dari aspek pertumbuhan ekonomi, sektor pertanian, peternakan, perikanan, dan kehutanan mampu merupakan salah satu yang mampu tumbuh positif di saat sebagian besar sektor lain tumbuh negatif (Darwin, 1999; Susilo \& Handoko, 2002; Mahdi, 2014).

Sektor pertanian sampai saat ini masih merupakan penyedia utama kebutuhan pangan masyarakat Indonesia, dimana kebutuhan tersebut merupakan kebutuhan dasar dan hak asasi manusia. Sektor pertanian juga menyediakan produk antara yang kemudian dimanfaatkan bagi sektor lain sebagai bahan baku (Syafa'at \& Mardianto, 2002). Lebih lanjut, pertanian juga berperan terhadap penyediaan lapangan kerja dan penyumbang devisa negara (Arifin dalam Isbah \& Iyan, 2016).

Setiawan (2006) menyampaikan bahwa selama periode 1996-2002, dari 10 orang pekerja di Indonesia, sekitar 4 atau 5 orang diantaranya bekerja di sektor pertanian.
Kemudian, berdasarkan data sakernas tahun 2006, dari total penduduk Indonesia yang bekerja dalam bidang pertanian mencapai 44,2 persen dari total 95.177 .102 orang. Fakta bahwa pertanian merupakan sektor pengganda kesempatan kerja terbesar dibandingkan sektor lain perlu menjadi perhatian pemerintah, agar program penciptaan lapangan kerja di Indonesia tidak meninggalkan salah satu sektor primer ini (Hakim et al., 2017).

Adanya status kejadian luar biasa (KLB), kebijakan karantina wilayah atau pembatasan sosial berskala besar, maka permintaan terhadap produk pertanian diproyeksikan menurun. Sebagai contoh, restauran dan kafe yang biasa membutuhkan produk pertanian, harus mengurangi konsumsinya karena saat ini kunjungan untuk makan di tempat dibatasi bahkan dilarang, sehingga berdampak pada jumlah permintaan yang berkurang. Di sisi lain, pada tingkat rumah tangga, konsumsi terhadap pangan cenderung meningkat, karena semakin banyak masyarakat yang beraktifitas di rumah, sehingga pengeluaran konsumsi bergeser dan terkonsentarasi pada kebutuhan pokok bukan makanan siap saji.

Kenaikan permintaan pangan oleh rumah tangga harus direspon dengan ketersediaan barang. Dengan demikian, harga yang diterima konsumen dapat terjaga. Namun demikian, jika direspon terlambat, maka akan terjadi ekses permintaan yang dapat menyebabkan kenaikan harga (Tambunan, 1996). Hal ini akan memberikan dampak terhadap masyarakat, khususnya pada golongan ekonomi lemah (Purwaningsih, 2008).

Berdasarkan hasil survei pertanian antar sensus 2018, rata-rata luas lahan yang dikuasai rumah tangga pertanian adalah 927,07 hektar, 880,9 hektar, dan 5.490 
hektar, masing-masing untuk lahan sawah irigasi, non-irigasi, dan lahan bukan sawah (BPS, 2018). Menurut Adimihardja (2006) dan Ritung (2010), di antara berbagai jenis lahan yang ada, sawah merupakan penghasil utama bahan pangan, yaitu gabah yang kemudian diolah menjadi beras.

Dengan luasan yang relatif sempit, upaya yang dapat dilakukan untuk meningkatkan produksi bahan pangan adalah intensifikasi. Intensifikasi pertanian diartikan sebagai pemanfaatan lahan yang tersedia secara optimal sehingga terjadi kenaikan produktifitas (Ahmadi \& Rahaju, 2018).

Berdasarkan hasil penelitian Ahmadi dan Rahaju (2018), program intensifikasi pertanian dengan memberikan penyuluhan oleh dinas pertanian dan subsidi pupuk dan benih telah berjalan baik. Namun demikian, fasilitas teknologi pertanian belum memadai karena 1 gabungan kelompok tani hanya diberi bantuan 1 traktor. Alat dan mesin pertanian memiliki peran strategis, karena mekanisasi dapat mendorong peningkatan produktivitas dan berdampak positif pada kenaikan pendapatan (Prayoga \& Sutoyo, 2017).

Sudirah et al. (2020) berpendapat bahwa intensifikasi pertanian dapat dilakukan dengan panca usaha tani, yaitu pengolahan tanah yang baik, irigasi yang teratur, pemilihan bibit unggul, pempukan, dan pemberantasan hama penyakit. Pada aspek pemupukan, petani masih menghadapi kendala fluktuasi harga pupuk bersubsidi sebagai akibat saluran distribusi yang tidak efektif. Namun demikian, petani tetap harus membeli karena pemupukan merupakan hal esensial dalam budidaya tanaman (Darwis \& Nurmanaf, 2004).

Lebih lanjut, Nugroho et al. (2018) mengungkapkan bahwa permasalahan dalam distribusi pupuk bersubsidi relatif kompleks dimana aktor yang terlibat juga relatif banyak. Permasalahan di tingkat distributor antara lain: keterlambatan pengecer menebus pupuk, manajemen administrasi di tingkat pengecer, mutu pupuk dari produsen, keterbatasan transportasi, dan kesalahan laporan hasil verifikasi dan validasi. Permasalahan di tingkat pengecer, yaitu: kualitas pupuk, adminitstrasi, kuantitas (berat) pupuk kurang sesuai, keterlambatan penyaluran, dan pengemasan. Sementara itu, petani sebagai konsumen akhir menganggap bahwa berdasarkan indikator tepat jenis, waktu, tempat, jumlah, harga, dan mutu, tidak ada yang 100 persen efektif.

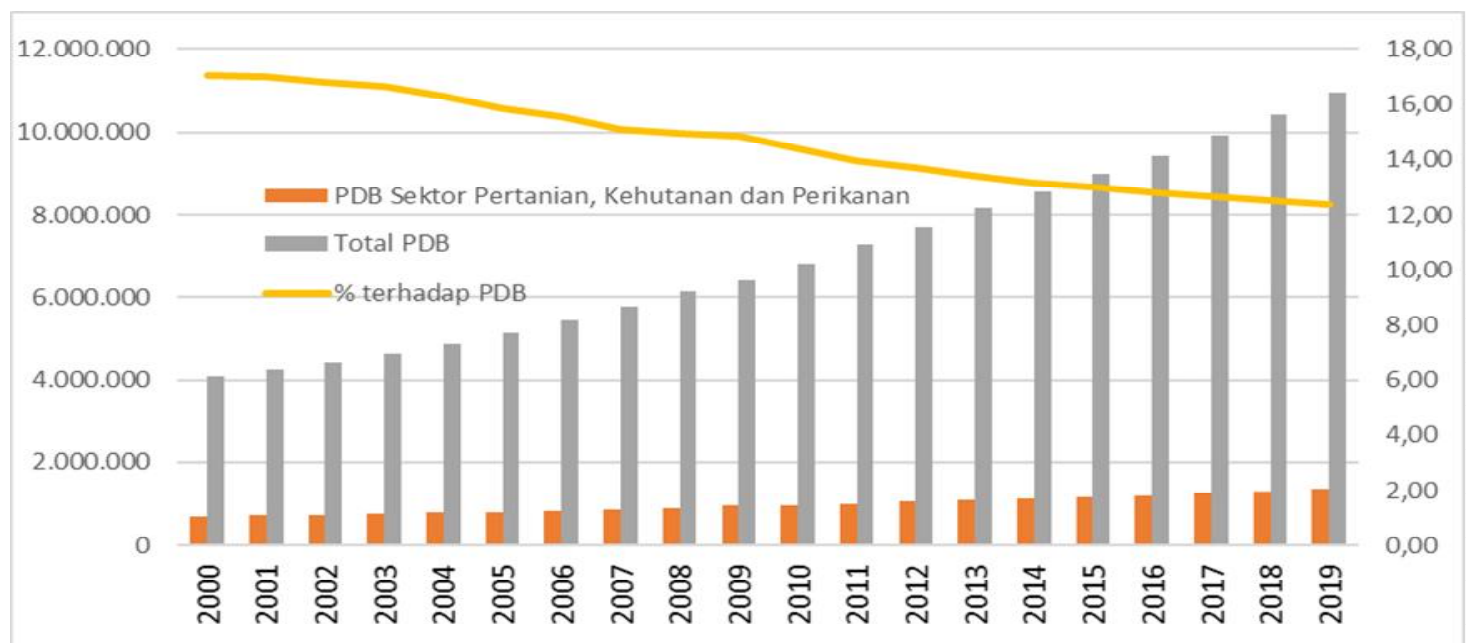

Gambar 1. PDB Sektor Pertanian, Kehutanan, dan Perikanan dan Total PDB Indonesia menurut ADHK 2010, 2000 - 2019 (Sumber: BPS (diolah)) 
Bahkan indikator tepat jumlah, harga dan tepat waktu, masing-masing berada di angka 28,57 persen, 52,38 persen dan 66,67 persen.

Keterlambatan pupuk berimbas pada penggunaan pupuk yang tidak optimal. Dampak lanjutannya adalah dapat menurunkan produksi tanaman (Neonbota \& Kune, 2016; Muliyanti et al., 2019). Jika penurunan produktifitas terus terjadi, maka keputusan rasional yang diambil oleh petani pada umumnya adalah menjual lahan (Putra \& Ismail, 2017).

Potret kendala yang dihadapi sektor pertanian ini dapat menjadi pertimbangan pemerintah dalam mengelola dampak pandemi COVID-19 terutama dari aspek ketenagakerjaan. Hal ini dikarenakan, pada setiap 1 hektar usahatani padi menyerap kurang lebih 88 hari orang kerja dengan kontribusi sebesar 50 persen terhadap total biaya produksi (Sahara et al., 2013). Dengan demikian, apabila intensifikasi berjalan lancar, maka semakin banyak tenaga kerja yang dapat diserap, dan di sisi lain ketersediaan bahan pangan mampu mengimbangi jumlah permintaan.
Penelitian ini bertujuan untuk: 1) melakukan kajian peran sektor pertanian terhadap pembangunan ekonomi di Indonesia, dan 2) melakukan simulasi terhadap realokasi anggaran kartu pra kerja untuk intensifikasi pertanian.

\section{BAHAN DAN METODE}

Metode penelitian ini adalah deksriptif analitis yaitu suatu metode yang memberikan gambaran keadaan yang sebenarnya dari obyek yang diteliti berdasarkan fakta-fakta yang ada dengan cara mengumpulkan, mengolah, dan menganalisis berbagai macam data sehingga dapat ditarik suatu kesimpulan (Rori, 2013). Data yang digunakan dalam penelitian ini berasal dari Badan Pusat Statistik dan Kementerian Pertanian.

Tujuan pertama dan kedua diketahui dengan analisis deskriptif. Pada tujuan pertama, dijabarkan mengenai kontribusi sektor pertanian terhadap pendapatan domestik bruto dan penyerapan tenaga kerja. Sementara itu, tujuan kedua diakukan simulasi dengan asumsi beberapa pos anggaran kartu pra kerja dialokasikan untuk

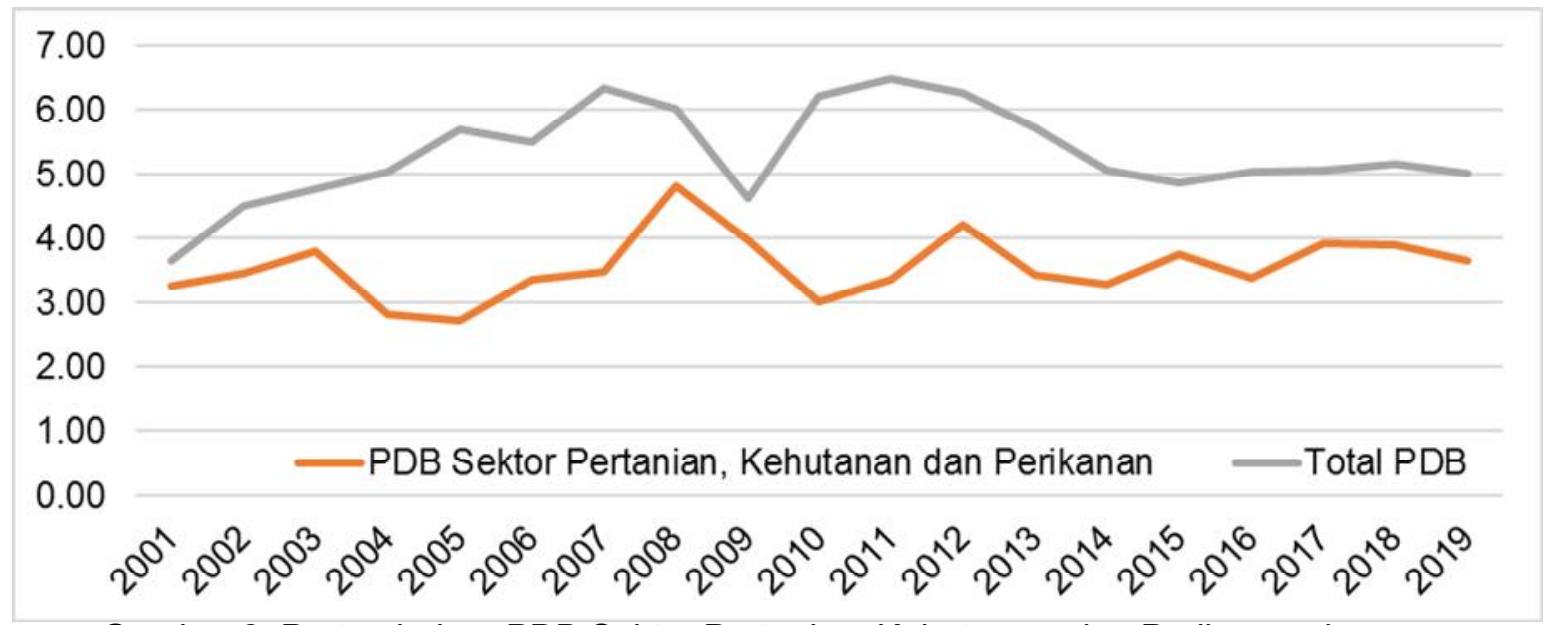

Gambar 2. Pertumbuhan PDB Sektor Pertanian, Kehutanan, dan Perikanan dan

Pertumbuhan total PDB di Indonesia, 2001- 2019 (Sumber: BPS (diolah)) 
intensifikasi pertanian. Dalam penelitian ini dipilih komoditas padi yang merupakan tanaman pangan untuk memenuhi kebutuhan pokok masyarakat Indonesia.

\section{HASIL DAN PEMBAHASAN}

3.1. Sektor Pertanian dan Pendapatan Domestik Bruto

Pendapatan domestik bruto dapat ditinjau dari tiga pendekatan, yaitu pengeluaran (rumah tangga, pelaku usaha, pemerintah, dan perdagangan (net ekspor), pendapatan, dan produksi. Pada pendekatan produksi, pendapatan domestik bruto diartikan sebagai nilai tambah yang dihasilkan oleh semua sektor kegiatan ekonomi (lapangan usaha) di suatu negara.

Sejak tahun 2000 hingga 2019, kontribusi sektor pertanian, kehutanan, dan perikanan terus menurun dengan rata-rata 0,25 persen per tahun. Hal ini dapat diartikan sebagai penurunan kapasitas produksi di sektor pertanian, kehutanan, dan perikanan maupun sebagai sinyal bahwa aktifitas perekonomian di Indonesia semakin bergeser menuju negara berbasis industri atau jasa. Publikasi BPS mengenai PDB Indonesia pada tahun 2014-2019 menyebutkan bahwa industri pengolahan berkontribusi di atas $20 \%$ dari total PDB selama 5 tahun terakhir. Sementara itu, sektor informasi dan komunikasi, konstruksi, dan jasa keuangan mencatat kenaikan kontribusi terbesar yaitu $0,89 \%, 0,47 \%$, dan $0,31 \%$.

Parameter lain terkait kontribusi sektor pertanian dan PDB adalah pertumbuhan dari waktu waktu. Dalam kurun waktu 19 tahun terakhir, rata-rata pertumbuhan ekonomi Indonesia sekitar 5,03 persen. Sementara itu, pada periode yang sama, sektor pertanian, kehutanan, dan perikanan mengalami rata-rata pertumbuhan sebesar 3,55 persen.

3.2. Sektor Pertanian dan Penyerapan Tenaga Kerja

Indonesia mendapatkan julukan sebagai negara agraris karena mayoritas penduduknya bekerja di sektor pertanian. Sejak tahun 2011 hingga 2019, lebih dari 30 juta penduduk berusia 15 tahun yang tergolong angkatan kerja mengandalkan

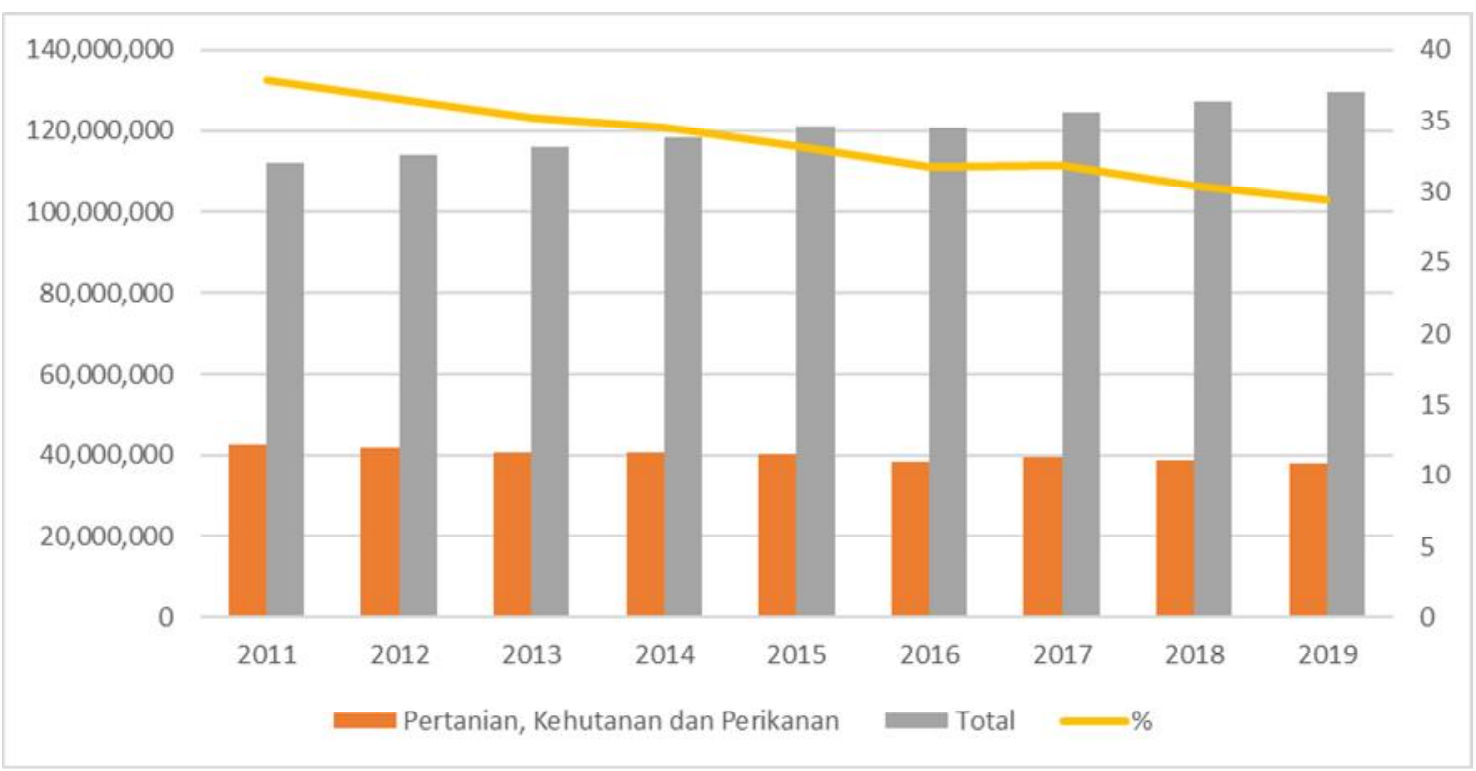

Gambar 3. Penduduk usia 15 tahun ke atas yang bekerja di sektor pertanian, kehutanan, dan perikanan di Indonesia, 2011 - 2019 (Sumber: BPS (diolah)) 
pertanian, kehutanan, maupun perikanan sebagai mata pencaharian. Pada peringkat kedua yaitu sektor perdagangan besar dan eceran, reparasi, dan perawatan mobil dan sepeda motor dengan jumlah tenaga kerja pertanian. Dengan demikian, biaya produksi dapat terkendali dan pendapatan petani yang notabene jumlahnya relatif banyak di Indonesia juga dapat terjaga.

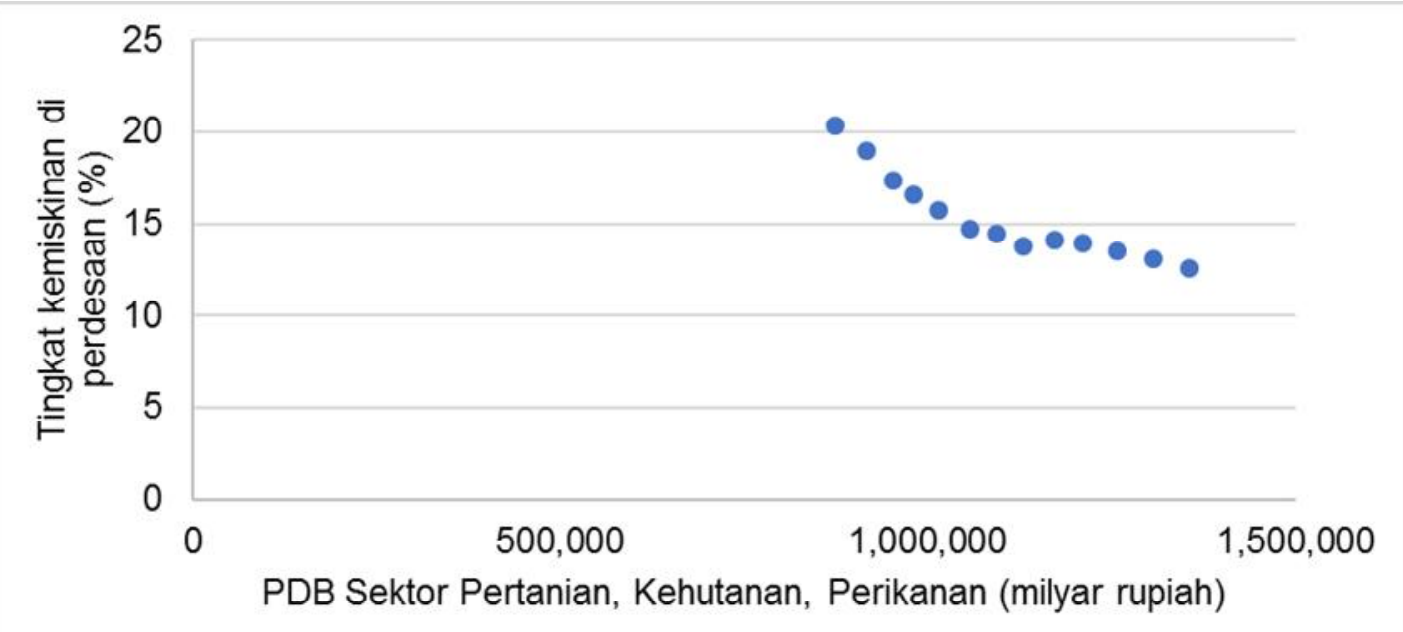

Gambar 4. PDB Sektor Pertanian, Kehutanan, Perikanan terhadap Tingkat Kemiskinan di perdesaan di Indonesia (Sumber: BPS (diolah))

sebanyak 24,4 juta orang.

Perubahan struktur ekonomi di Indonesia berpengaruh juga terhadap komposisi tenaga kerja di sektor pertanian. Pertumbuhan di sektor industri maupun jasa menyebabkan adanya mobilitas tenaga kerja dari pertanian menuju non pertanian (Nugroho, Waluyati, et al., 2018). Semakin langkanya tenaga kerja, maka akan mendorong kenaikan upah yang harus dibayarkan pemilik lahan/penggarap lahan. Apabila diasumsikan harga jual dan produktifitas tetap, maka pendapatan petani akan tergerus, bahkan bukan tidak mungkin rugi. Oleh karena itu, pada umumnya opsi yang biasa diambil adalah meningkatkan curahan tenaga kerja dalam keluarga.

Oleh sebab itu, intervensi pemerintah terhadap intensifikasi pertanian, dapat dilakukan salah satunya dengan meningkatkan suplai tenaga kerja di sektor

\subsection{Sektor Pertanian dan Tingkat Kemiskinan}

Hermawan (2012) berpendapat bahwa meskipun kemiskinan bersifat multidimensi dan multisektoral, ada keterkaitan yang erat antara kemiskinan dengan sektor pertanian. Distribusi keluarga miskin didominasi oleh sektor pertanian, jasa, dan terakhir sektor industri (Hermawan, 2012). Di Indonesia, kantong kemiskinan terbagi menjadi dua wilayah, yaitu perkotaan dan perdesaan. BPS dalam publikasinya mengenai tingkat kemiskinan, menginformasikan bahwa perdesaan menempati peringkat pertama dengan persentase sebesar 12,6 persen, sementara di perkotaan 6,56 persen.

Tingkat kemiskinan yang relatif lebih besar menjadi alasan mengapa penduduk desa memutuskan untuk berpindah ke kota, dengan harapan akan mendapatkan pendapatan yang lebih tinggi atau 
setidaknya probabilitas memperoleh kesempatan untuk bekerja mejnjadi lebih besar (Monanisa et al., 2013). Wilayah perdesaan yang didominasi oleh pekerjaan di sektor pertanian, tidak memiliki banyak ruang untuk kesempatan bekerja, karena produktifitas relatif sama dari waktu ke waktu, harga jual relatif stabil, sedangkan biaya produksi cenderung meningkat.

Akan tetapi, apabila terjadi sebaliknya, maka sektor pertanian akan mampu menyerap tenaga kerja lebih banyak atau dapat juga meningkatkan curahan waktu kepada tenaga kerja yang ada. Gambar 4 menunjukkan keterkaitan antara PDB sektor pertanian, kehutanan, perikanan terhadap tingkat kemiskinan di perdesaan. Dapat disimpulkan bahwa terdapat keterkaitan di antara semakin tinggi PDB sektor pertanian, dengan tren penurunan tingkat kemiskinan di perdesaan.

Melalui perhitungan atas dasar harga konstan tahun 2010, pada tahun 2007, PDB sektor pertanian mencapai 874 triliun rupiah. Kemudian pada tahun 2019, nilai tersebut meningkat 55 persen menjadi 1.354 triliun rupiah. Sementara itu, tingkat kemiskinan di perdesaan pada tahun 2007 sebesar 20,37 persen. Pada tahun 2019, persentase tersebut menurun hingga menjadi 12,6 persen.

\subsection{Sektor Pertanian dan Tingkat Kemiskinan}

Pada tahun 2015, pemerintah menerbitkan program upaya khusus untuk meningkatkan produksi padi, jagung dan kedelai (PAJALE). Program ini merupakan bagian dari target pencapaian swasembada pangan berkelanjutan yang telah ditetapkan pemerintah, dan harus tercapai dalam waktu tiga tahun. Sebagai bentuk keseriusan pemerintah, pada tahun 2015 disiapkan dana dalam jumlah besar dari Anggaran Pembangunan Belanja Negara Perubahan
(APBN-P) 2015 sebesar Rp. 16,8 triliun. Dana tersebut kemudian disalurkan kepada petani dalam bentuk bantuan benih, pupuk, perbaikan irigasi, alat dan mesin pertanian (Ponto et al., 2017).

Juhandi \& Enre (2019) melakukan kajian mengenai dampak program UPSUS PAJALE terhadap daerah basis produksi. Hasil penelitiannya menyimpulkan bahwa terdapat penambahan wilayah basis produksi padi, jagung, dan kedelai. Dari sisi produksi, UPSUS PAJALE terbukti meningkatkan kuantitas produk yang dihasilkan.

Keberhasilan melalui program UPSUS ini dapat menjadi landasan berfikir bahwa upaya pemerintah yang terkonsentrasi pada komoditas tertentu akan membuahkan hasil yang relatif lebih baik dan terukur dibandingkan berfokus ke beragam komoditas.

Dalam mengelola dampak pandemi COVID19 di sektor pertanian, kementerian pertanian telah menetapkan tiga kebijakan yaitu: 1. Melakukan refocusing kegiatan dan anggaran sebagai antisipasi dampak pandemi virus COVID-19, 2. Mempercepat program padat karya, 3. Menjaga ketersediaan bahan pangan pokok. Adapun langkah strategis yang telah ditetapkan adalah: 1) penyediaan bahan pangan pokok utamanya beras dan jagung bagi 267 juta masyarakat Indonesia, 2) percepatan ekspor komoditas strategis dalam mendukung keberlanjutan ekonomi, 3) sosialisasi kepada petani dan petugas untuk melakukan pencegahan berkembangnya virus corona, 4. Pembuatan/pengembangan pasar tani di setiap provinsi, optimalisasi pangan lokal, koordinasi infrastruktur logistik, dan emarketing, dan 5. Program/kegiatan padat karya agar sasaran pembangunan pertanian dicapai dan masyarakat langsung menerima dana tunai (Kementerian Pertanian, 2020). 
Kajian simulasi realokasi anggaran kartu pra kerja dalam mendukung intensifikasi sektor pertanian ini sejalan dengan poin-poin pada kebijakan kementerian pertanian. Kebijakan kartu pra kerja yang terkesan tergesa-gesa dan belum tersampaikan dengan jelas kepada masyarakt mengenai luaran yang ingin dicapai.

Total dana 5,6 triliun rupiah diberikan oleh pemerintah kepada penyelenggara pelatihan atau dengan kata lain 1 juta rupiah untuk satu peserta pelatihan. Kemudian, tersedia dana 840 miliar rupiah sebagai insentif dari pemerintah untuk pengisian survei kebekerjaan selama tiga kali dalam tiga bulan. Terakhir, disediakan dana 600 ribu rupiah per bulan selama tiga bulan kepada peserta yang mengikuti pelatihan. Untuk poin terakhir, dapat diasumsikan ini adalah bentuk pemberian bantuan langsung tunai oleh pemerintah untuk menjaga daya beli masyarakat. Namun untuk dua insentif lainnya, sepertinya pemerintah perlu membuka ruang lebih luas lagi dengan memperhatikan sektor primer di Indonesia.

Alasan perlu dilakukannya realokasi anggaran kartu pra kerja antara lain: 1. Pada saat seperti ini, para penyedia lapangan kerja cenderung menahan untuk membuka rekrutmen baru. Bahkan, yang terjadi justru relatif banyak pekerja dirumahkan sebagai akibat roda bisnis yang lambat berputar atau justru berhenti bergerak. 2. Ketika pandemi COVID-19 dinyatakan berakhir, para pelaku usaha tetap perlu beradaptasi dengan menggunakan sumber daya yang ada. Sangat besar kemungkinan, pekerja yang telah dirumahkan akan kembali dipekerjakan, sehingga probabilitas untuk membuka lowongan pekerjaan baru semakin kecil, khususnya dalam jangka pendek. 3 . Para pekerja informal dari ibukota tidak lagi bekerja hingga akhirnya memutuskan untuk pulang ke kampung halaman. Di wilayah perdesaan, untuk mengakses pelatihan secara online tentu tidak mudah karena keterbatasan alat/perangkat maupun jaringan, 4. Warga perantauan yang kembali ke perdesaan, dapat mengandalkan pendapatan yang telah disimpan selama bekerja di luar daerah asal. Namun demikian, simpanan tersebut akan habis jika tidak diikuti dengan pemasukan. Dengan demikian, pada titik tertentu, pasokan tenaga kerja yang ada di desa akan bertambah. Hal ini merupakan momentum yang tepat untuk melibatkan tenaga kerja tersebut di sektor pertanian.

Simulasi pertama, dana pelatihan untuk penyelenggara pelatihan online dikurangi 50 persen dan dana insentif survei kebekerjaan seluruhnya dialokasikan di sektor pertanian, tersedia anggaran untuk subsidi budidaya padi sebesar 3,64 triliun rupiah. Dengan menggunakan asumsi ongkos produksi usaha tanaman padi sawah pada musim kemarau tahun 2017 yang diterbitkan BPS, maka tambahan dana tersebut dapat membantu sepenuhnya petani dengan luas lahan sebesar 285.266 hektar (biaya per hektar sebesar Rp. 12,76 juta) atau lebih besar dibandingkan dengan luas lahan sawah Provinsi Aceh pada tahun 2018 (254.361 hektar) atau gabungan luas lahan sawah Kepulauan Riau (625 hektar), DKI Jakarta (217 hektar), Bengkulu (86.160 hektar), Jambi (81.849 hektar), dan Riau (35.643 hektar).

Dengan asumsi rata-rata produktivitas lahan sebesar 4,7 ton per hektar, maka akan diperoleh gabah kering giling sebanyak 1.516.189 ton atau setara dengan 898.822 ton beras. Apabila menggunakan asumsi konsumsi per kapita sebanyak $6,5 \mathrm{~kg}$ beras per minggu atau setara $26 \mathrm{~kg}$ per bulan, maka dengan simulasi pertama ini, realokasi kartu pra kerja dapat menyediakan beras kepada 34.570.115 jiwa selama satu bulan dengan harga terjangkau agar bisa diakses khususnya bagi kalangan ekonomi lemah. 
Hasil penjualan tersebut selanjutnya dialokasikan untuk bagi hasil kepada pemilik lahan.

Lebih lanjut, di dalam struktur ongkos usahatani padi sawah, dari total biaya produksi Rp. 12,76 juta, sebanyak Rp. 6,23 juta dialokasikan untuk tenaga kerja. Dengan demikian, keberpihakan pemerintah terhadap intensifikasi pertanian dapat menjaga daya beli masyarakat dengan tepat sasaran. Hanya individu yang bekerja yang diberikan upah. Upah yang diberikan juga tepat waktu.

Simulasi kedua, pelatihan melalui online tetap dilaksanakan dengan anggaran yang sudah ditentukan. Akan tetapi, anggaran survey kebekerjaan sepenuhnya dialokasikan untuk intensiikasi pertanian. Atas dasar hal tersebut, rencana pemerintah untuk pengumpulan data status kerja peserta kartu Pra Kerja bisa dilakukan secara sukarela seperti halnya survey yang telah dilakukan pemerintah pada umumnya, salah satu contohnya sensus kependudukan.

Total realokasi anggaran sebesar 0,84 triliun rupiah dapat digunakan untuk subsidi usahatani padi seluas 65.831 hektar. Total produksi beras diperkirakan dapat mencapai 207.422 ton. Jumlah penerima beras melalui program ini dapat mencapai 7,97 juta orang dalam satu bulan.

Apabila diperkirakan bahwa selama satu musim tanam, pemilik lahan membutuhkan 99,43 hari orang kerja per hektar (Lagebada et al., 2017). Bahkan, angka tersebut dapat lebih besar jika melibatkan proses panen hingga pengelolaan pasca panen. Kajian Kawengian et al. (2019) menghitung bahwa rata-rata curahan tenaga kerja pada usahatani padi sawah sejak pengolahan tanah hingga pengeringan hasil panenan menapai 136 hari orang kerja. Adapun rincian persentasenya, pengolahan tanah
$(6,4 \%)$, persemaian bibit $(3,3 \%)$, penanaman $(24,6 \%)$, penyiangan $(16,9 \%)$, pemupukan $(6,6 \%)$, panen $(23,6 \%)$, pengangkutan $(2,3 \%)$, dan pengeringan $(9,6 \%)$.

Dengan demikian, adanya tambahan anggaran subsidi untuk sektor pertanian dengan luasan lahan 65.831 hektar, kebutuhan curahan waktu tenaga kerja mencapai sekitar 8.952.978 HOK. Kemudian, diasumsikan setiap individu memiliki kemampuan yang sama dan dapat bekerja 8 jam per hari atau setara 1 HOK. Maka, dapat terserap tenaga kerja sebanyak 37.304 orang untuk satu musim tanam padi.

\section{KESIMPULAN}

Tujuan pemerintah mempercepat realisasi kartu pra kerja di tengah pandemi COVID-19 merupakan salah satu upaya untuk mengelola dampak agar tidak semakin luas. Pemberian dana insentif pelatihan, tidak berbeda halnya seperti bantuan langsung tunai, namun spesifik untuk para pencari kerja, individu yang terkena PHK, pelaku usaha yang gulung tikar, dan pekerja yang ingin meningkatkan ketrampilannya. Intensifikasi pertanian dapat menjadi pilihan untuk realokasi angaran kartu pra kerja. Sektor pertanian merupakan sektor padat karya dan hingga saat ini menduduki peringkat pertama penyerapan tenaga kerja. Di sisi lain, terjadinya krisis pada waktu yang lalu menjadi bukti bahwa sektor ini mampu bertahan. Penyebabnya adalah setiap individu membutuhkan pangan sebagai kebutuhan pokok. Sehingga, keberpihakan terhadap sektor pertanian, berimplikasi kepada keberpihakan terhadap penyediaan pangan. Dari sudut pandang ketenagakerjaan, terdapat dua simulasi realokasi anggaran. Pertama, pengurangan anggaran untuk lembaga pelatihan sebesar $50 \%$ dan realokasi sepenuhnya insentif survey kebekerjaan. Kedua, hanya realokasi $100 \%$ dana survey kebekerjaan. Apabila hal ini dilakukan, maka tenaga kerja dapat 
terserap secara efektif. Dampak positif lain, ketersediaan bahan pangan melimpah sehingga dapat menyediakan pangan dengan harga terjangkau, khususnya untuk kalangan ekonomi lemah.

\section{DAFTAR PUSTAKA}

Adimihardja, A. (2006). Strategi Mempertahankan Multifungsi Pertanian di Indonesia. Jurnal Penelitian Dan Pengembangan Pertanian, 25(3).

BPS. 2018. Hasil Survei Pertanian Antar Sensus (SUTAS) 2018. Badan Pusat Statistik. Jakarta

Ahmadi, F. F., \& Rahaju, T. (2018). Impelementasi Program Intensifikasi Pertanian Sub Sektor Padi pada Gapoktan Mukti Jaya Desa Sidomukti Kecamatan Kembangbahu Kabupaten Lamongan. Publika, 6(6).

Astuti, P. B. (2016). Analisis Kurva Phillips dan Hukum Okun di Indonesia tahun 1986-2016. Jurnal Fokus Bisnis, 15(01), 7291.

https://doi.org/10.1017/CBO97811 07415324.004

Darwin, M. (1999). Krisis Nasional: Respons Penduduk Miskin dan Pemerintah. Populasi, 10(1), 114.

Darwis, V., \& Nurmanaf, A. R. (2004). Kebijakan Distribusi, Tingkat Harga dan Penggunaan Pupuk di Tingkat Petani. Forum Penelitian Agro Ekonomi, 22(1), 63-73. https://doi.org/10.21082/fae.v22n1 .2004.63-73

Direktorat Jenderal Pencegahan dan Pengendalian Penyakit. 2020. Pedoman Pencegahan dan Pengendalian Coronavirus Disease (COVID-19). Kementerian Kesehatan Republik
Indonesia.

Franita, R. (2016). Analisa Pengangguran Di Indonesia. Jurnal IImu Pengetahuan Sosial, 1, 88-93. http://jurnal.umtapsel.ac.id/index.php/nusantara/a rticle/viewFile/97/97

Gugus Tugas Percepatan Penanganan COVID-19. 2020. Peta Sebaran. https://covid19.go.id/peta-sebaran. Diakses pada tanggal 30 April 2020.

Hakim, A. R., Setiawan, R. R., Nasir, M. S., Suripto, \& Khasanah, U. (2017). Perubahan Struktur Ekonomi dan Kesempatan Kerja Di Indonesia (Analisa Input Output ). Konferensi Nasional Penelitian Matematika Dan Pembelajarannya II, 58-66.

Hermawan, I. (2012). Analisis Eksistensi Sektor Pertanian terhadap Pengurangan Kemiskinan di Pedesaan dan Perkotaan. MIMBAR, 28(2), 135-144.

Isbah, U., \& Iyan, R. Y. (2016). Analisis Peran Sektor Dalam Perekonomian Dan Kesempatan Kerja Pertanian Di Provinsi Riau. Jurnal Sosial Ekonomi Pembangunan, 7(19), 45-54.

Jayani, D., H. 2020. Wabah PHK Akibat Covid-19. Wabah PHK Akibat Covid-19.

https://katadata.co.id/infografik/20 20/04/18/wabah-phk-akibat-covid19. Diakses pada tanggal 30 April 2020.

Juhandi, D., \& Enre, A. (2019). Kebijakan Upsus Pajale: Mampukah Menambah Provinsi Basis Produksi Pajale? Habitat, 30(3), 123-131. https://doi.org/10.21776/ub.habitat .2019.030.3.15 
Kawengian, T., Mandey, J. R., \& Waney, N. F. L. (2019). Curahan Tenaga Kerja pada Usahatani Padi di Desa Lowian Kecamatan Maesaan. Agri-SosioEkonomi, 15(3), 397-406.

Kementerian Pertanian. 2020. Kementan Tanggap Covid-19. https://www.pertanian.go.id/home/ ?show=page \&act=view\&id=99.

Diakses pada tanggal 30 April 2020

Lagebada, D. R., Effendy, \& Sulaeman. (2017). Analisis Pendapatan dan Kelayakan Usahatani Padi Sawah di Desa Maranatha Kecamatan Sigi Biromaru Kabupaten Sigi. EJurnal Agrotekbis, 5(4), 509-517.

Lidwina, Andrea. 2019. Kartu Prakerja, Strategi Kurangi Pengangguran. https://katadata.co.id/infografik/20 19/12/11/kartu-prakerja-strategikurangi-pengangguran. Diakses pada tanggal 30 April 2020.

Mahdi. (2014). Elastisitas Investasi dan Pengaruhnya terhadap Pertumbuhan PDB Sektor Pertanian di Indonesia. Jurnal Serambi Ekonomi \& Bisnis, 1(1), 5-10.

Monanisa, Soebyakto, B. B., \& Erlina, L. (2013). Analisis Alasan Migrasi Masuk di Kota Muaradua Kabupaten Oku Selatan Setelah Pemekaran Wilayah. DeJoS, 1(1).

Muliyanti, S., Rianse, U., \& Abdullah, W. G. (2019). Faktor-Faktor Yang Mempengaruhi Produksi Padi Sawah (Oriza Sativa L) di Kelurahan Unaasi Kecamatan Anggaberi Kabupaten Konawe. Jurnal Ilmiah Membangun Desa Dan Pertanian, 4(4), 94-101. https://doi.org/10.24843/jma.2017. v05.i02.p09

Neonbota, S. L., \& Kune, S. J. (2016).
Faktor-Faktor

yang

Mempengaruhi Usahatani Padi

Sawah di Desa Haekto

Kecamatan Noemuti Timur.

Agrimor, 1(3), 32-35.

https://doi.org/10.32938/ag.v1i03.

104

Nugroho, A. D., Siregar, A. P., Andanari, E., Shafiyudin, Y., \& Christie, J. I. (2018). Distribusi Pupuk Bersubsidi di Kabupaten Bantul Provinsi Daerah Istimewa Yogyakarta. Agrisocionomics, 2(1), 70-82.

Nugroho, A. D., Waluyati, L. R., \& Jamhari, J. (2018). Upaya Memikat Generasi Muda Bekerja Pada Sektor Pertanian di Daerah Istimewa Yogyakarta. JPPUMA: Jurnal IImu Pemerintahan Dan Sosial Politik Universitas Medan Area, 6(1), 76-95. https://doi.org/10.31289/jppuma.v $6 i 1.1252$

Ponto, J., Benu, N. M., \& Kumaat, R. M. (2017). UPSUS PAJALE DALAM MENUNJANG PROGRAM SWASEMBADA PANGAN DI KABUPATEN BOLAANG MONGONDOW. AgriSosioEkonomi, 13(2A), 253-260.

Prasetyoningrum, A. K., \& Sukmawati, U. S. (2018). Analisis Pengaruh Indeks Pembangunan Manusia (IPM), Pertumbuhan Ekonomi dan Pengangguran Terhadap Kemiskinan Di Indonesia. Equilibrium: Jurnal Ekonomi Syariah, 6(2), 217-240. https://doi.org/10.21043/equilibriu m.v6i2.3663

Prayoga, A., \& Sutoyo. (2017). Produktivitas dan Pendapatan Usahatani Padi Sawah dampak Program Bantuan Alat Mesin Pertanian, Benih dan Pupuk di Kabupaten Malang Provinsi Jawa 
Timur. Jurnal IImu-IImu Pertanian, 24(1), 1-9.

Purwaningsih, Y. (2008). Ketahanan pangan: situasi, permasalahan, kebijakan, dan pemberdayaan masyarakat. Jurnal Ekonomi Dan Pembangunan, 9(1), 1-27.

Putra, D. E., \& Ismail, A. M. (2017). Faktor-Faktor yang Mempengaruhi Petani dalam melakukan Alih Fungsi Lahan di Kabupaten Jember. Agritech, XIX(2), 99-109.

Qomariyah, I. (2013). Pengaruh Tingkat Inflasi Dan Pertumbuhan Ekonomi Terhadap Tingkat Pengangguran Di Jawa Timur. Jurnal Pendidikan Ekonomi (JUPE), 1(3).

Ritung, S. (2010). Lahan Sawah dan Kecukupan Produksi Bahan Pangan. Jurnal Sumberdaya Lahan, 4(1), 27-38.

Rori, H. (2013). Analisis Penerapan Tax Planning Atas Pajak Penghasilan Badan. Jurnal Riset Ekonomi, Manajemen, Bisnis Dan Akuntansi, 1(3), 410-418.

Sahara, D., Kushartanti, E., \& Suhendrata, T. (2013). Kinerja usahatani padi dengan mesin transplanter dalam rangka efisiensi tenaga kerja. SEPA, 10(1), 55-62.

Setiawan, I. (2006). Peran Sektor Pertanian Dalam Penyerapan Tenaga Kerja Di Indonesia. Jurnal Geografi Gea, 6(1). https://doi.org/10.17509/gea.v6i1. 1733

Sudirah, Santoso, A., Sumartono, \& Syukur, M. (2020). Hubungan Penguatan Modal Sosial, Mitigasi Bencana Banjir dan Peningkatan Produksi Pertanian. Equilibrium: Jurnal Pendidikan, VIII(1).
Susilo, Y. S., \& Handoko, B. S. (2002). Dampak Krisis Ekonomi Terhadap Kinerja Sektor Industri: Pendekatan Model Keseimbangan Umum Terapan Indorani. Jurnal Ekonomi Dan Bisnis Indonesia, 17(3), 243-257. https://doi.org/10.22146/jieb.v17i3. 6721

Syafa'at, N., \& Mardianto, S. (2002). Identifikasi Sumber Pertumbuhan Output Nasional: Pendekatan Analisis Input-Output. JAE, 20(1), $1-24$.

https://doi.org/10.21082/jae.v20n1 2002.1-24

Tambunan, T. (1996). Sumber Inflasi dan Kebijaksanaan Kontraktif di Indonesia. Ekonomi Dan Keuangan Indonesia, XLIV(1), 5573.

https://doi.org/10.7454/efi.v44i1.14 0

Yudanto, N., \& Santoso, M. S. (1998). Dampak Krisis Moneter Terhadap Sektor Riil. Buletin Ekonomi Moneter Dan Perbankan. https://doi.org/10.21098/bemp.v1i 2.164 